\title{
Review \\ Oxide Metallurgy Technology in High Strength Steel: A Review
}

\author{
Wei Liang ${ }^{1}$, Ruming Geng ${ }^{1}$, Jianguo $\mathrm{Zhi}^{2,3, *}$, Jing $\mathrm{Li}^{1, *}$ and Fei Huang ${ }^{1}$ \\ 1 State Key Laboratory of Advanced Metallurgy, University of Science and Technology Beijing, \\ Beijing 100083, China; b20200579@xs.ustb.edu.cn (W.L.); ustbgrm@163.com (R.G.); \\ huangfei19960923@163.com (F.H.) \\ 2 Inner Mongolia Enterprise Key Laboratory of Rare Earth Steel Products Research and Development, \\ Baotou 014010, China \\ 3 Inner Mongolia Baotou Steel Union Co., Ltd., Baotou 014010, China \\ * Correspondence: zjiang64@sina.com (J.Z.); lijing@ustb.edu.cn (J.L.)
}

Citation: Liang, W.; Geng, R.; Zhi, J.; Li, J.; Huang, F. Oxide Metallurgy Technology in High Strength Steel: A Review. Materials 2022, 15, 1350. https://doi.org/10.3390/ ma15041350

Academic Editor: Tomasz Lipiński

Received: 13 January 2022

Accepted: 8 February 2022

Published: 11 February 2022

Publisher's Note: MDPI stays neutral with regard to jurisdictional claims in published maps and institutional affiliations.

Copyright: (c) 2022 by the authors. Licensee MDPI, Basel, Switzerland. This article is an open access article distributed under the terms and conditions of the Creative Commons Attribution (CC BY) license (https:// creativecommons.org/licenses/by/ $4.0 /)$.

\begin{abstract}
Oxide metallurgy technology plays an important role in inclusion control and is also applied to improve the weldability of high strength steel. Based on the requirements of the weldability in high strength steel, the influencing factors of weld heat affected zone (HAZ) as well as the development and application status of oxide metallurgy technology are summarized in this review. Moreover, the advantages and difficulties in the application of rare earth (RE) oxide metallurgy technology are analyzed, combined with the performance mechanism of RE and its formation characteristics of fine and high melting point RE inclusions with distribution dispersed in liquid steel. With the weldability diversities of different high strength steels, the research status of weldability of high strength steel with high carbon equivalent and the effects of RE on the microstructure and properties of HAZ are discussed, and some suggestions about further research in the future are proposed.
\end{abstract}

Keywords: high strength steel; heat affected zone; oxide metallurgy technology; rare earth; rare earth inclusion; second phase

\section{Introduction}

High strength low alloy (HSLA) steel, a weldable low carbon engineering structure steel, is obtained by adding a small amount of $\mathrm{Mn}, \mathrm{Si}, \mathrm{Nb}, \mathrm{V}, \mathrm{Ti}, \mathrm{Al}$ and other alloy elements into ordinary carbon steel and subjecting it to a heat treatment process. Because of low $\mathrm{C}$ content, low crack sensitivity, fine microstructure, and high strength and toughness, it is widely used in bridges, buildings, ships, high pressure vessels, construction machinery, and other fields [1]. Furthermore, the comprehensive properties of high strength steel have been improved significantly with the development and application of refining technology, thermo mechanical control process (TMCP), thermomechanical treatment, and thin slab continuous casting and rolling [2,3]. It is well known that welding is the most common means of building engineering structures. However, the toughness of the weld HAZ is significantly lower than that of base metal after the welding thermal cycle in high strength steel, possibly resulting in structural failure. In order to avoid significant deterioration of HAZ toughness, in recent years, fundamental measures have been adopted to improve the weldability of the base metal matrix by determining the influencing factors of microstructure and properties of HAZ, in addition to using the appropriate welding process. A series of oxide metallurgy technologies have been developed $[4,5]$ that control the formation of fine and dispersed high melting point inclusions in liquid steel, and they affect the size, morphology, and distribution of sulfide, carbonitride, and other non-metallic inclusions. The technologies have improved the weldability of high strength steel by making full use of these inclusions to pin the austenite grain boundary and induce the formation of acicular ferrite (AF) during the welding thermal cycle [6].

As an "industrial vitamin", there are many studies on the function mechanisms of rare earth (RE) in steel. The studies using RE to modify inclusions and improving steel 
microstructure and properties through the control of RE inclusions are also gradually increasing [7-9]. In addition, disperse high melting point RE inclusions are used to pin the austenite grain boundary and induce AF nucleation during the welding, which can also play the role in oxide metallurgy technology [10]. However, for high strength steel with high carbon equivalent, it is difficult to form $\mathrm{AF}$, and easy to produce brittle structures such as upper bainite. There is great importance to study the measures to improve the weldability and the function mechanisms of RE in HAZ.

Based on the control of microstructure and properties of HAZ in high strength steel, this paper assesses the influencing factors of microstructure and properties in HAZ and the development and application of oxide metallurgy technology. Moreover, the effects of RE oxide metallurgy technology on HAZ are also presented. For the weldability of high strength steel with high carbon equivalent, the current measures and the influences of RE on improving the microstructure and properties of HAZ are discussed. The theoretical supports for enriching the application mechanism of RE in steel and broadening oxide metallurgy technology are further provided.

\section{Research Status of Oxide Metallurgy Technology in Steel}

\subsection{Influencing Factors of Microstructure and Properties in HAZ}

The welding HAZ is a whole zone where the structure and properties of the unmelted base metal on both sides of the weld fusion line change under the conditions of the thermal cycle. The microstructure and temperature range of HAZ in high strength steel are shown in Figure 1. According to the distance from the weld center, it is divided into a melting zone, coarse grain zone, fine grain zone, two phase zone, and tempering zone, and the corresponding microstructure and temperature range are also shown. The coarse grain zone has large grains and poor toughness, so it is the weak zone of the HAZ and of entire welded joint. In addition, chemical composition, austenite grain size, and cooling speed are identified as the major factors that affect the microstructure and properties of HAZ [11,12].

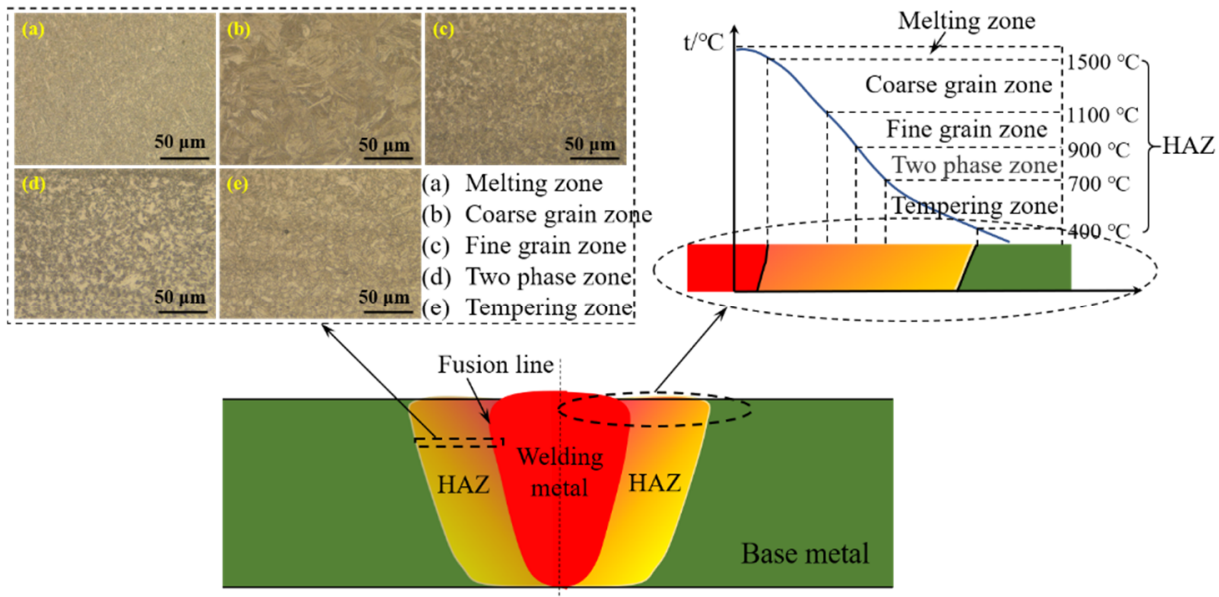

Figure 1. Structure and temperature range of HAZ in high strength steel. (Reproduced with permission from ref. [13]. Copyright 2008 China Academic Journal Electronic Publications.)

\subsubsection{Chemical Composition}

In high strength steel, the increased $C$ content can reduce the ductility and toughness and improve the sensitivity of the welding crack. As for the steel with good weldability, the $\mathrm{C}$ content is generally not more than $0.20 \mathrm{wt} \%$, or even lower. The effects of carbon content and carbon equivalent on the weldability of steel are described in Figure 2. Zone I is the easy welding zone (around $\mathrm{C}<0.13 \%$, Ceq $>0$ ), and the steel in this zone can be welded directly. Zone II is the general welding zone (around C $>0.13 \%, 0<\mathrm{Ceq}<0.5 \%$ ); the steel in this zone has high requirements for the welding process, so preheating before welding and heat treatment after welding are ordinarily required to ensure the performance of welded 
joints. Zone III is the hard welding zone (around C $>0.1 \%$, Ceq $>0.5 \%$ ), and the steel in this zone has low requirements for weldability. $\mathrm{Mn}$ is usually added to steel to offset the strength loss due to carbon reduction. The initial transformation temperature of ferrite is decreased by adding $\mathrm{Mn}$, which promotes the formation of $\mathrm{AF}$ and affects the toughness of the HAZ [14]. In contrast, the Si content increased in steel can inhibit the formation of AF and increase content of the grain boundary ferrite (GBF) and M-A structure [15], and it leads to lower ductility and toughness. The content of $S$ and $P$ is generally limited to a low range, otherwise the weldability of the steel will deteriorate. $\mathrm{Al}$ is a strong deoxidizer but also a nitrogen fixing agent. The austenite grain boundary can be effectively pinned by nanoscale AlN below $1100{ }^{\circ} \mathrm{C}$, whereas the composite inclusion of $\mathrm{Al}$ also induces $\mathrm{AF}$ nucleation and refines grains [16]. However, $\mathrm{Al}_{2} \mathrm{O}_{3}$ inclusions aggregate easily to form clusters, becoming a crack source. With proper content of $\mathrm{Nb}, \mathrm{Ti}$ and $\mathrm{C}, \mathrm{N}$ in steel, fine carbonitrides can be easily formed, which together play the role of pinning grain boundaries in the welding thermal cycle [17]. Oxides and nitrides of Ti used to induce AF also improve welding toughness [18]. Nevertheless, the excessive $\mathrm{Ti}$ and $\mathrm{Nb}$ will lead to coarsening carbonitrides and deteriorating toughness. The carbonitrides of $\mathrm{V}$ precipitated in the austenite zone can inhibit the grain growth of austenite, and carbonitrides precipitated in the ferrite zone can increase the nucleation core of AF [19]. However, when welding heat input is high, they will not work. The formation temperature of carbides containing $\mathrm{Cr}$ is low, such as $\mathrm{M}_{7} \mathrm{C}_{3}$, which basically cannot play a role in the welding thermal cycle. $\mathrm{Ni}$ is an element that expands the austenite zone. It can affect the diffusion rate of carbon and alloy elements, improve the hardenability, and slow down the hardening cracking trend during welding [20]. Generally, proper Mo in steel enables complete bainite structure to be obtained in a wide range of cooling speeds and realize the uniformity of HAZ structure [21]. The segregation of trace $B$ at the grain boundary can reduce the grain boundary energy so as to decrease the driving force of grain growth during welding [22]. Moreover, BN also promotes ferrite nucleation during cooling. Therefore, the content of carbon and other alloys should be considered in steel design, and the characteristics of disperse inclusion particles should be also fully utilized.

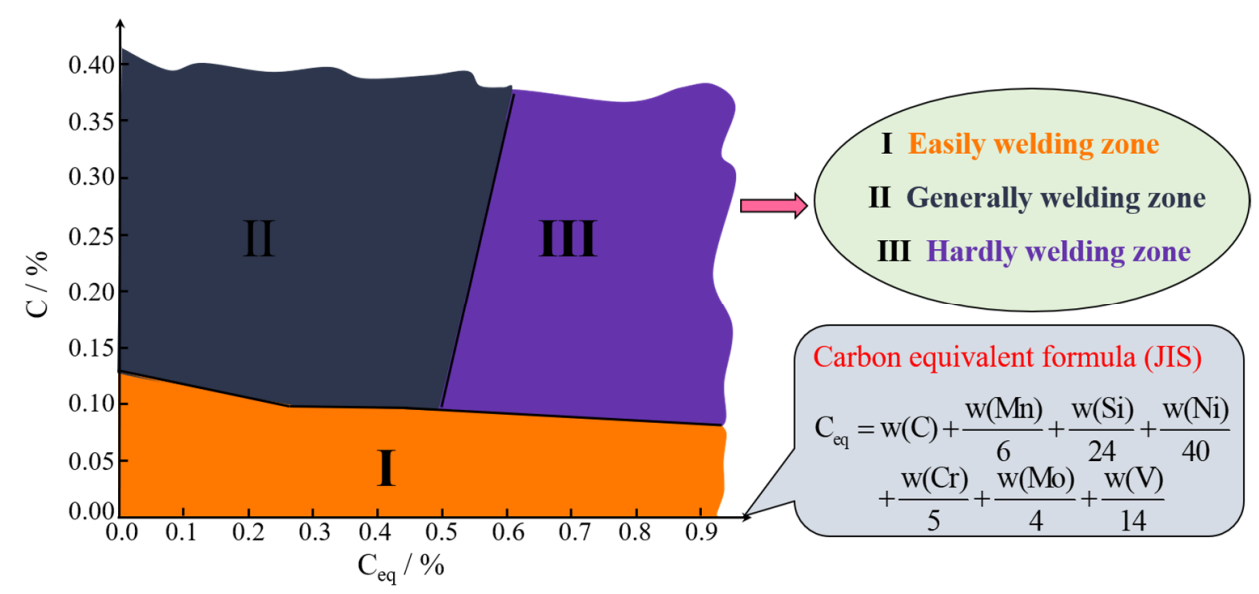

Figure 2. Effects of carbon content and carbon equivalent on weldability of high strength steel. (Reproduced with permission from [23]. Copyright 2004 China Academic Journal Electronic Publications.)

\subsubsection{Austenite Grain Size}

The toughness of the HAZ in steel is primarily affected by austenite grain coarsening, and its coarsening is closely related to welding heat input. Shome [24] studied the relationship between the peak temperature and austenite grain size of HAZ in HSLA-100 steel. The peak temperature of fusion line in $\mathrm{HAZ}$ is $1450{ }^{\circ} \mathrm{C}$, and the peak temperature and grain size decrease with the increasing distance from the fusion line, as shown in Figure 3a. With the increase of peak temperature, the grain size also increases significantly, as shown in Figure $3 b$. 

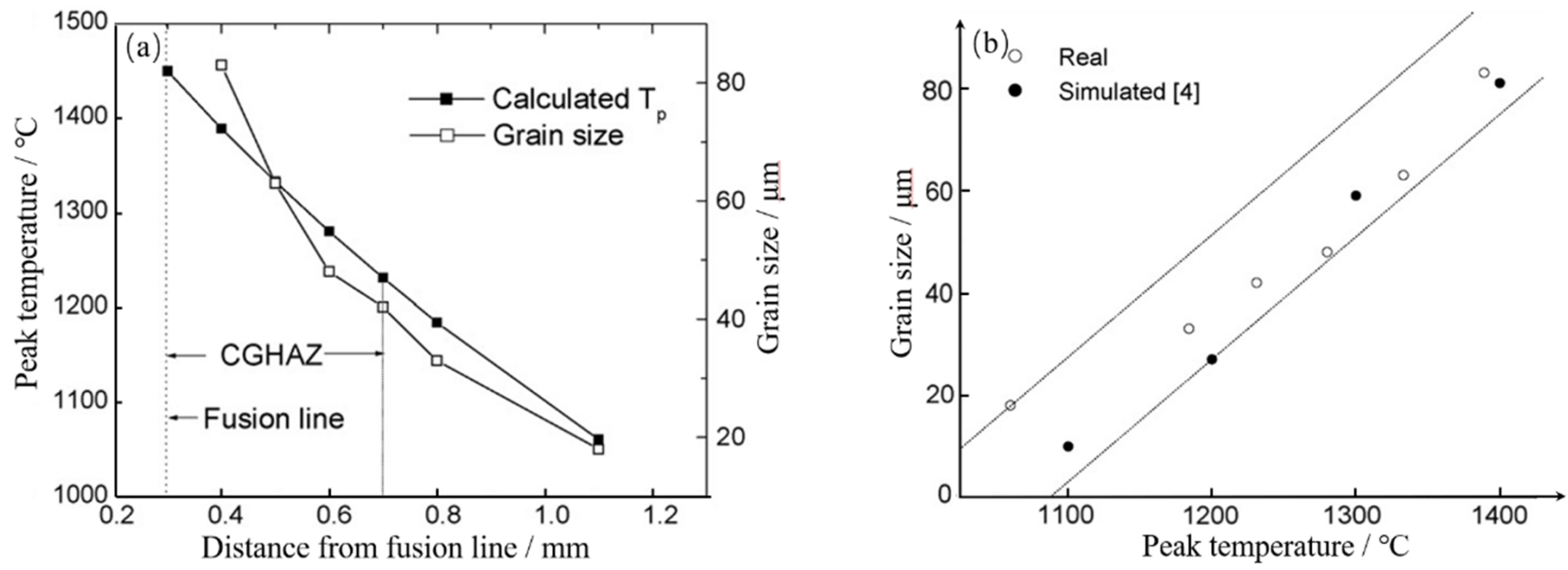

Figure 3. Peak temperature and austenite grain size of HAZ in HSLA-100 steel. (a) The relationship of peak temperature and distance from fusion line; (b) the relationship of grain size and peak temperature. (Reproduced with permission from [24]. Copyright 2007 Elsevier Publications.)

Further, the grain size is also affected by the second phase particles. Most of the particles begin to dissolve at $1200{ }^{\circ} \mathrm{C}$ with grain coarsening. The coarsening of grain has a direct influence on its transformation in the cooling process and the morphology of transformation products, thus affecting the weldability of steel to some degree. The relationship between austenite grain size (D), second phase size $(d)$, and second phase volume fraction $(f)$ is expressed by the follow equation [25]:

$$
\mathrm{D}=\frac{\pi d}{6 f}\left(\frac{3}{2}-\frac{2}{Z}\right)
$$

where $\mathrm{Z}$ is used to represent the ratio of the maximum grain diameter to the average grain diameter. It is concluded that the size and volume fraction of second phase precipitates is of great importance to grain growth. Therefore, the relation of welding heat input and second phase should be balanced according to the service conditions of different types of steel in order to form the optimal grain size.

\subsubsection{Cooling Speed}

In addition to austenite grain coarsening, cooling speed also affects the microstructure and properties of HAZ in steel. The cooling speed after welding is expressed by the cooling time $\left(\mathrm{t}_{8 / 5}\right)$ between $800{ }^{\circ} \mathrm{C}$ and $500{ }^{\circ} \mathrm{C}$. Generally, the transformation microstructures are martensite and bainite when $t_{8 / 5}$ is short. The microstructures are primarily GBF, ferrite side plate (FSP), and AF when $\mathrm{t}_{8 / 5}$ is medium. They are primarily polygonal ferrite (PF), GBF, and pearlite when $t_{8 / 5}$ is long [26,27]. Fang et al. [28] studied the microstructure evolution of the welding coarse grain zone in V-Ti steel. The results showed that when $\mathrm{t}_{8 / 5}$ was $7.5 \mathrm{~s}$, the coarse grain zone was primarily martensite lath. GBF, PF, and some granular bainite were formed with $\mathrm{t}_{8 / 5}$ changing from $20 \mathrm{~s}$, to $40 \mathrm{~s}$, to $100 \mathrm{~s}$, and the ferrite size increased significantly.

The influencing factors of $t_{8 / 5}$ and its relationship with low temperature impact toughness of HAZ are shown in Figure 4 . When affecting the microstructure of HAZ, $\mathrm{t}_{8 / 5}$ is directly related to heat input, plate thickness, thermal conductivity, specific heat, steel density, and initial temperature, and indirectly related to welding methods, preheating, and heat treatment after welding. Within limits, the impact toughness of HAZ decreases significantly when $t_{8 / 5}$ is increased, as shown in Figure 4 . More importantly, heat input, welding mode, preheating (affecting initial temperature), and heat treatment after welding are controllable among the relevant factors of $t_{8 / 5}$ and these factors should be the subjects of future research focused on obtaining excellent microstructures. 

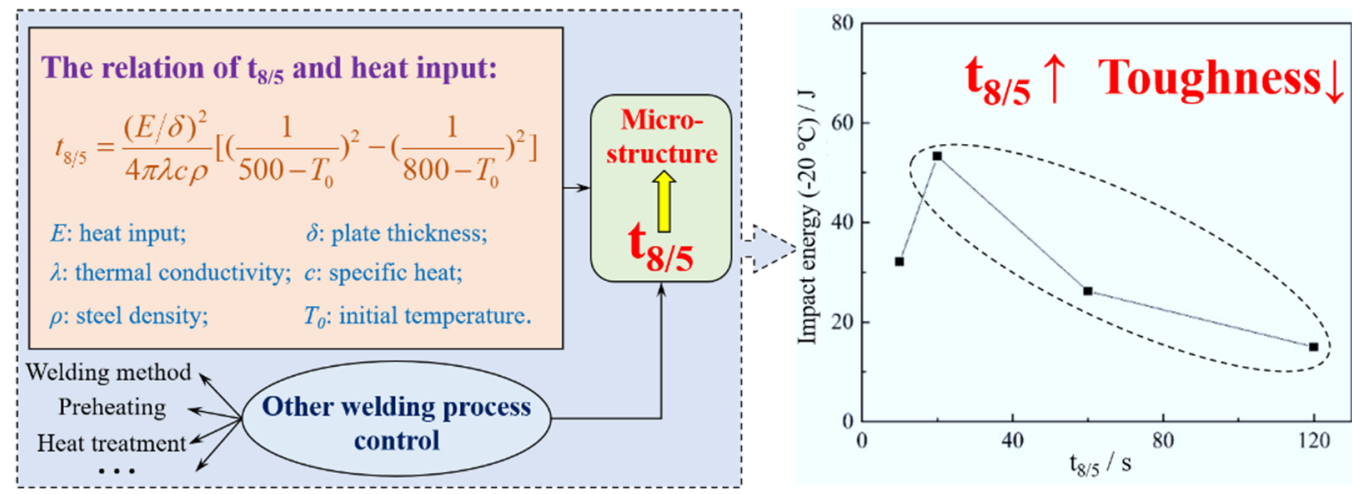

Figure 4. Influence factors of $t_{8 / 5}$ and its relationship with low temperature impact toughness of HAZ. (Reproduced with permission from [29]. Copyright 2013 Elsevier Publications.)

\subsection{Development of Oxide Metallurgy Technology}

Many studies and practical work were initially carried out by Japanese scholars on the application of oxide metallurgy technology, which effectively improves the weldability of high strength steel. Nippon Steel has long been committed to utilizing oxide metallurgy technology to improve the HAZ toughness of steel, and its development process is shown in Figure 5. In the 1970s, fine and dispersed TiN particles were proposed to inhibit austenite grain coarsening during welding so as to reduce the brittleness of HAZ. Subsequent studies found that TiN dissolved or aggregated easily when the peak welding temperature exceeded $1400{ }^{\circ} \mathrm{C}$. The technology of Ti deoxidation treatment had been used to form stable high melting point oxide inclusions in steel since the 1990s [30]. And $\mathrm{Ti}_{2} \mathrm{O}_{3}$ inclusions and composite inclusions could be used to promote AF nucleation. However, $\mathrm{Ti}_{2} \mathrm{O}_{3}$ aggregated and grew easily in refined liquid steel, and it was difficult to obtain fine inclusions. After the year of 2000, super high HAZ toughness technology with fine microstructure impacted by fine particles (HUTFF) as the third-generation oxide metallurgy technology was developed. It was based on the characteristic that basic metal (such as $\mathrm{Mg}, \mathrm{Ca}$ ) oxides or sulfides could stably exist at $1400{ }^{\circ} \mathrm{C}$. These inclusions were to pin austenite grain boundaries and induce AF during cooling [31], which refined microstructure and improved welding toughness. Nippon Steel then increased the ability to induce AF nucleation by adjusting the alloy compositions to promote the formation of Mn-depleted zone according to HUTFF technology [32].

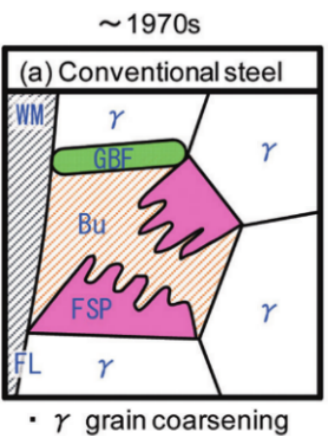

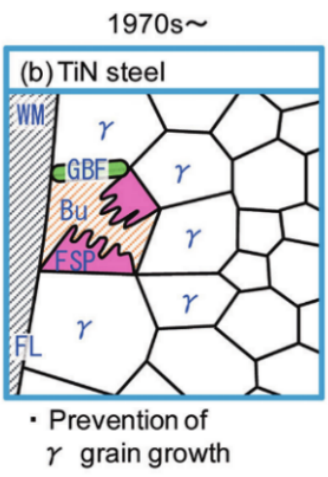

Prevention of $\gamma$ grain growth 1990s

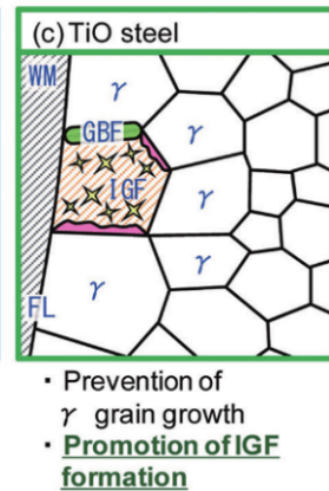

2000s

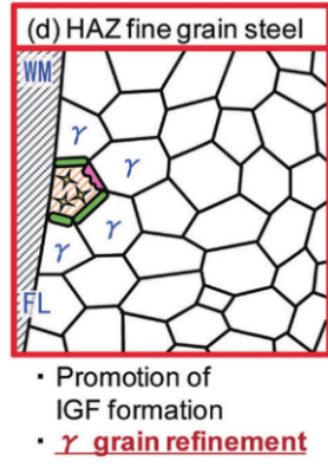

WM: Weld Metal, FL: Fusion Line, $\gamma$ :Austenite, GBF: Grain Boundary Ferrite, FSP: Ferrite Side Plate, IGF: Intra Granular Ferrite, Bu: Upper Bainite

Figure 5. Development of HAZ toughening technology at Nippon Steel. (Reproduced with permission from [32]. Copyright 2018 Nippon Steel Corporation Publications.) 
In 2004, JFE Shoji Trade Corporation (JFE) successfully developed excellent quality in large heat input welded joints (EWEI) technology to improve the toughness of HAZ from three aspects: controlling the grain size, adjusting the intragranular structure, and optimizing the alloy composition and production process [33]. The specific processes included raising the TiN solution temperature, reducing carbon equivalent, and increasing the nucleation particles of $\mathrm{BN}$ and $\mathrm{Ca}$ inclusions, and using a super online accelerated cooling (super-OLAC) process, respectively [34-36]. In addition, the formation of Ti oxide and the segregation of B at the grain boundary in steel were controlled by Kobe Steel through adjusting the content of Ti and B in the 1980s, which worked together on the pinning grain boundary and the nucleation of AF. Kobe super toughness (KST) technology was expanded to improve welding toughness [37,38]. Subsequently, the composition was adjusted around the fine control of the bainite structure of high strength steel to improve the driving force of phase transformation, and "low-carbon multi-directional bainite" composition technology was developed [39].

In addition, Chinese enterprises and scientific research institutes have also done relevant research on oxide metallurgy technology. The researchers of Wuhan Iron and Steel Group Corp. (WISCO) strictly controlled the content of carbon and alloy when designing the steel composition. Dispersed micron $\mathrm{Ti}, \mathrm{Nb}$ carbonitrides and nanoscale high melting point $\mathrm{Mg}$, Ca oxysulfide were used to pin high temperature austenite grain boundaries and induce AF. Thus, steel grades with heat input of $50-200 \mathrm{~kJ} / \mathrm{cm}$ and $200-400 \mathrm{~kJ} / \mathrm{cm}$ were developed, respectively [40,41]. Baosteel researchers conducted studies on revealing the metallurgical mechanism of $\mathrm{Mg}$, $\mathrm{Ca}$ oxides. The fine and dispersed oxide sulfide particles generated in the steel were fully utilized to pin the grain boundary and induce AF effectively. High strength steel with excellent weldability was developed: the average impact energy at $-20^{\circ} \mathrm{C}$ was $142 \mathrm{~J}$ under $400 \mathrm{~kJ} / \mathrm{cm}$ heat input [42]. With the production of low-carbon microalloyed steel, the researchers of Anshan Iron and Steel Group Corporation (AISC) adopted an unconventional deoxidation alloying process to control the formation of $\mathrm{Ti}$ composite inclusions with the size of $1 \mu \mathrm{m}$, inducing and refining ferrite grains. Compared with the conventional deoxidation process, the tensile strength and low temperature impact strength of the steel were increased by $24.56 \%$ and $24.00 \%$, respectively. A range of ship plate steel products for high heat input welding were developed [43]. Furthermore, Yang's team from Shanghai University had long studied the effects of $\mathrm{Mg}$ treatment on inclusions in steel and the properties of welding HAZ, and they concluded that Mg treatment could refine inclusions and improve the toughness of HAZ [44-46]. Scholars from Northeastern University found that the low temperature impact toughness of HAZ were optimum when the $\mathrm{Zr}$ content in low carbon steel was $0.003 \%$. The $0.5 \sim 3 \mu \mathrm{m}$ composite inclusion formed with the appropriate addition of $\mathrm{Zr}$ in steel could induce AF nucleation and refine grains during welding thermal simulation cooling [47]. The effects of different composite deoxidizers (V-Ti, Ti-Al (or RE), Ti-Ca, etc.) on the microstructure and properties of HAZ were also studied [48-50]. Among them, Xia from Central Iron and Steel Research Institute (CISRI) added trace $\mathrm{Mg}$ and $\mathrm{Zr}$ to the Ti-treated steel. The size of Ti composite inclusions was reduced significantly, which promoted AF nucleation and improved the toughness of HAZ. The developed E36 high heat input ship plate steel could achieve heat input of $240 \mathrm{~kJ} / \mathrm{cm}$ [51]. Similarly, scholars from North China University of Science and Technology used Mg-Al-Ti compound deoxidation to produce $40 \mathrm{~mm}$ thick ship plate steel; the impact energy near the fusion line could reach $80 \%$ of the base metal under $150 \mathrm{~kJ} / \mathrm{cm}$ heat input [52].

Currently, oxide metallurgy technology used to improve the properties of HAZ in high strength steel has been partially industrialized. There are still some problems, however, such as accurately controlling the content of $\mathrm{Ti}, \mathrm{Ca}, \mathrm{Mg}$, and $\mathrm{Zr}$, and aggregating and easily growing high melting point inclusions. Therefore, the additional methods of alloy elements, refining processes, and fine dispersion control technology of inclusions should be further optimized, and the types of beneficial inclusions and their nucleation effect on AF also need to be clarified. With the development and application of RE resources, the 
studies on its function mechanisms in steel have made some progress. Results of previous research indicated that trace $R E$ added to high strength steel may significantly improve the toughness of HAZ [53].

\section{Research Status of RE Oxide Metallurgy Technology in Steel}

\subsection{Development of RE Oxide Metallurgy Technology}

Generally, the functions of RE in steel are purifying liquid steel, improving inclusions, and microalloying. As the most abundant RE elements in minerals, Ce and La are the most widely used in iron and steel metallurgy industry because of their active chemical properties and low price. Trace RE added to clean steel can remove $\mathrm{O}$ and $\mathrm{S}$ but can also reduce the segregation of harmful elements at grain boundaries through location competition and interaction [54]. The expansion coefficient and elastic modulus of RE inclusions are similar to those of the matrix, and its shapes are mostly circular and elliptical, which decrease additional stress and increase crack propagation energy during hot deformation and cooling [55]. In addition, the segregation of RE atoms affects the diffusion of other elements and the nucleation and growth of new phases, thus realizing microalloying [56].

Many high melting point oxides and sulfides can be formed in liquid steel because of the strong binding force between $\mathrm{O}, \mathrm{S}$, and RE. With the decrease of solubility product, new $\mathrm{RE}$ inclusions will continue to form during solidification, which achieves the requirements of oxide metallurgy technology for small size and dispersion of beneficial inclusions to some degree and promotes the development of RE oxide metallurgy technology.

Through welding E36 steel with RE welding wire, Yu et al. [57] found that the inclusions in the weld metal were the composite inclusions of (Ti-Al-Mn-Si-O) + (Ce-O-S) with the diameter of $0.5 \mu \mathrm{m}$, and the AF was induced by them, as shown in Figure 6 . In addition, the areas of AF in the weld metal were also increasing with added RE content, which could reach $85 \%$ when the Ce content was $0.032 \%$, and the impact energy at $-40{ }^{\circ} \mathrm{C}$ exceeded $82 \mathrm{~J}$. Deng et al. [58] studied the evolution of inclusions in steel and the nucleation mechanism of AF through experiments and thermodynamic calculations. It was concluded that (Mn-Al-Si-Ti-La-Ce-O) + MnS composite inclusions could be used as the particle of AF nucleation. The studies of Thewlis and Xue et al. $[59,60]$ also indicated that the morphology and distribution of inclusions were improved by RE, and RE inclusions could induce AF nucleation easily, refine the microstructure of weld metal, and improve the weldability of steel. Moreover, Cao et al. [10] observed that the disperse RE inclusions in HAZ pinned the grain boundary and were beneficial to grain refinement after adding Ce into X70 steel. Some research studies of RE oxide metallurgical technologies are shown in Table 1.
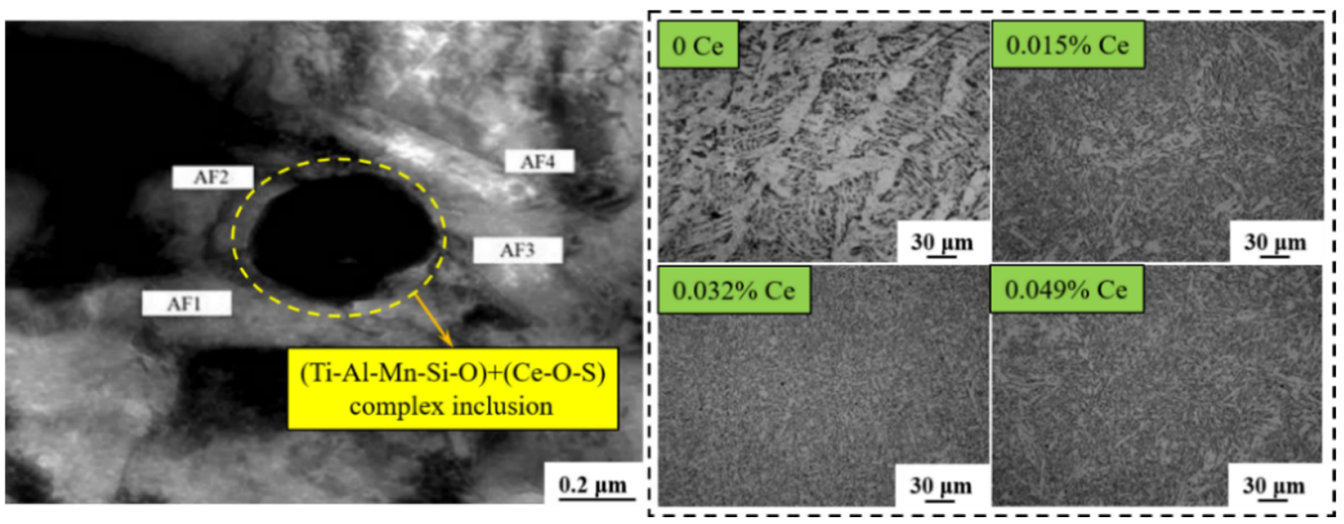

Figure 6. Microstructure of weld metal with different RE content. (Reproduced with permission from [57]. Copyright 2012 China Academic Journal Electronic Publications.) 
Table 1. Research on RE oxide metallurgical technology.

\begin{tabular}{|c|c|c|c|c|c|c|}
\hline $\begin{array}{l}\text { Carbon } \\
\text { Content } / \%\end{array}$ & $\begin{array}{l}\text { Carbon } \\
\text { Equivalent }\end{array}$ & $\begin{array}{c}\text { Rare Earth Elements } \\
\text { and Content } / \%\end{array}$ & Rare Earth Inclusions & Microstructure & Author & Time \\
\hline 0.12 & 0.27 & $0.02 \mathrm{Ce}$ & \multirow{6}{*}{$\begin{array}{c}\mathrm{Ce}_{2} \mathrm{O}_{2} \mathrm{~S}+\mathrm{CeAlO}_{3} \\
\text { Ti-RE- } \mathrm{Zr} \text { complex oxide } \\
\text { (La-Ce-Ca-Al-Mg-S) } \\
\text { complex oxide } \\
\mathrm{RE}_{2} \mathrm{O}_{2} \mathrm{~S}+\mathrm{MnS} \\
\mathrm{CeAlO}_{3} \\
\mathrm{La}_{2} \mathrm{O}_{2} \mathrm{~S}+\mathrm{MnS}\end{array}$} & $\mathrm{BF}, \mathrm{P}, \mathrm{IAF}$ & Wen et al. & 2012 [61] \\
\hline 0.04 & 0.30 & 0.0014 (Ce-La) & & $\mathrm{AF}$ & Nako et al. & 2015 [62] \\
\hline 0.15 & 0.41 & $0.006 \mathrm{Ce}+0.003 \mathrm{La}$ & & $\mathrm{PF}, \mathrm{F}$ & Chu et al. & $2018[63]$ \\
\hline 0.12 & 0.34 & 0.021 (Ce-La) & & $\mathrm{AF}, \mathrm{GBF}$ & Song et al. & 2019 [64] \\
\hline 0.05 & 0.36 & $0.05 \mathrm{Ce}$ & & $\mathrm{AF}, \mathrm{B}$ & Cao et al. & 2019 [10] \\
\hline 0.17 & 0.40 & $0.02 \mathrm{La}$ & & $\mathrm{AF}, \mathrm{FSP}, \mathrm{GBF}$ & Xie et al. & $2020[65]$ \\
\hline
\end{tabular}

Abbreviations: $\mathrm{BF}$, block ferrite; $\mathrm{P}$, pearlite; IAF, intragranular acicular ferrite; $\mathrm{AF}$, acicular ferrite; GBF, grain boundary ferrite; B, bainite; FSP, ferrite side plate.

The propagation path of cleavage crack of AF nucleated by RE inclusions is different from that of FSP. As shown in Figure 7, the FSP has the sheet structure parallel to the crystal orientation, which can provide a better path for crack propagation and reduce the crack propagation energy. However, the structure of AF lath crosses each other, which has a strong effect of hindering crack propagation [66]. Consequently, the fracture toughness of steel is improved with the increase of AF.

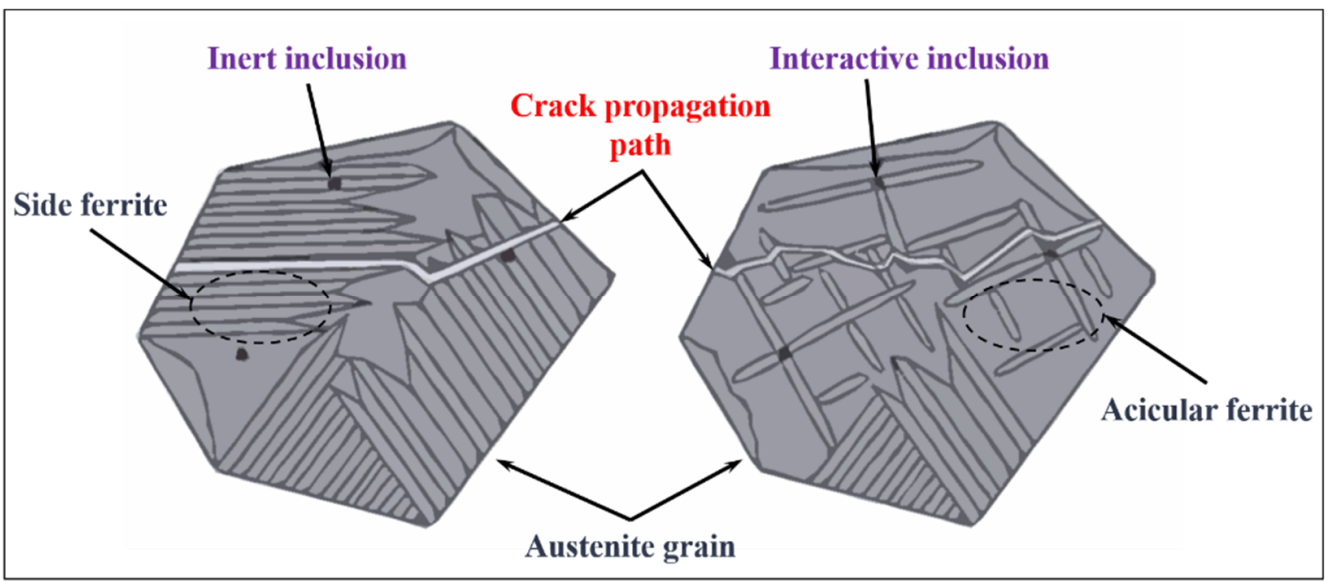

Figure 7. Schematic diagram of crack propagation path between FSP and AF. (Reproduced with permission from [66]. Copyright 2016 Doctoral Electronic Journal Publications.)

At present, the formation mechanisms of AF mainly include the solute element change mechanism, low mismatch mechanism, stress-strain mechanism, and inert interface energy mechanism. The solute element change mechanism refers to the absorption of austenitic stabilization elements (C, Mn, B, etc.) by non-metallic inclusions, resulting in the decrease of solute element content on the surface of inclusions, the advance of austenite to ferrite transformation, and the increase of AF nucleation probability [12]. The low mismatch mechanism means studying the lattice structure matching degree between non-metallic inclusions and $\alpha-\mathrm{Fe}$, and it is conducive to the reduction of interface energy and stress energy required for ferrite nucleation with a high matching degree [67]. For example, the mismatches between $\mathrm{Ce}_{2} \mathrm{O}_{3}, \mathrm{Ce}_{2} \mathrm{O}_{2} \mathrm{~S}, \mathrm{CeAlO}_{3}$, and $\alpha$-Fe are only $4.1 \%$, $1.2 \%$, and $7.0 \%$, respectively, so that they all have the chance to effectively induce the particles of AF [68]. Thus, the possibility of ferrite nucleation induced by inclusions can be explained theoretically by calculating the mismatches between different inclusions and $\alpha$-Fe. The two mechanisms noted are highly thought to explain the AF induction mechanism, yet there are still cases that cannot be fully explained by a single mechanism. Koseki [69] studied the influencing factors of AF in the weld metal and HAZ, and considered that the nucleation mechanism of AF in the weld metal was mainly the low mismatch mechanism, whereas the solute element change mechanism was mainly in HAZ. Furthermore, the combined action of two 
or more mechanisms should be discussed for the inclusions with different morphology and distribution.

\subsection{Some Application Difficulties of RE Oxide Metallurgy Technology}

Most scholars are focused on the study of the modification process of inclusions after RE addition and the capability of AF induced by different RE inclusions, yet the key technologies of controlling fine and dispersed RE inclusions are rarely studied [70-72]. As is generally known, RE in solid solution and RE inclusions are the main forms of RE in steel. The stability of total RE and different forms of RE in steel is crucial to ensuring the stability of RE action. The implementation of the latter depends on the stability of liquid steel cleanliness before RE addition, which is also conducive to the stable control of RE yield. The content of T.O, S, and RE have a significant influence on the formation and transformation of inclusions in RE-treated steel, thus the effects of T.O and S content on the quantity, type, size, and precipitation temperature of RE inclusions, as well as the cooperative control range of Ce, T.O, and S should be further analyzed.

In addition, key trace elements such as $\mathrm{Ca}$ and $\mathrm{Mg}$ also need to be systematically studied for the transformation of inclusions and the reaction with refractory in the refining process. In the case of carrying out RE treatment and cancelling Ca treatment, the authors' previous study indicated that the high melting point inclusion $\mathrm{Ce}_{2} \mathrm{O}_{3}$ formed in liquid steel reacted with $\mathrm{Al}_{2} \mathrm{O}_{3}$ in the refractory of the submerged entry nozzle (SEN) to form $\mathrm{CeAlO}_{3}$ [73]. The reaction products and other inclusions continued to accumulate, resulting in the formation of a clogging layer on the nozzle surface, as shown in Figure 8. By carrying out RE treatment and then Ca treatment in refining, Geng et al. [74] found that composite inclusions of $\mathrm{Ca}, \mathrm{Al}$, and $\mathrm{RE}$ were formed, as shown in Figure 9, which may not be beneficial to the oxide metallurgy of RE inclusions. Therefore, the effects of only RE treatment, the sequence of $\mathrm{Ca}$ treatment and RE treatment, and the addition amount of them on inclusion evolution, SEN clogging, and plate properties should be studied, so the optimization of refining process and the application of RE oxide metallurgy technology can be improved.

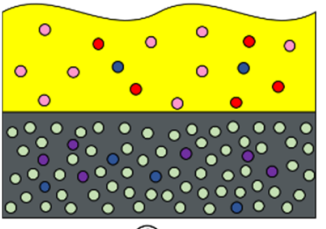

(1)

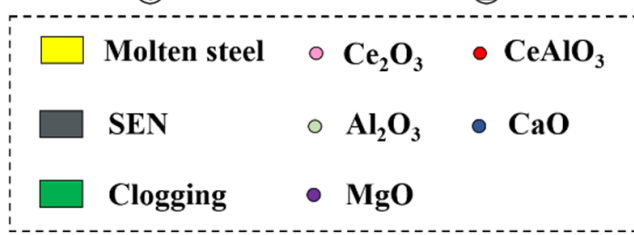

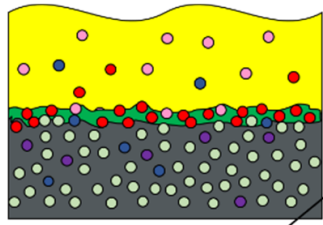

(3)

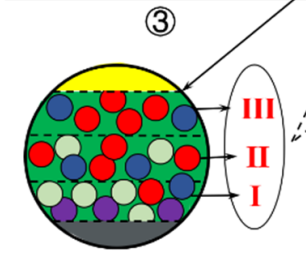

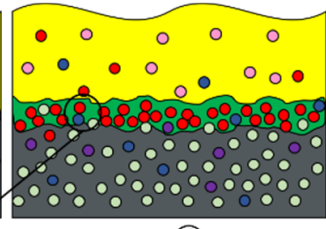

(4)

I-First reaction zon

II -Second reaction zon III-Third reaction zone

Figure 8. Schematic diagram of clogging formation in SEN. (1) Inclusion suspension, (2) Inclusion reaction, (3) Clogging formation, (4) Clogging aggregation (Reproduced with permission from [73]. Copyright 2021 Springer Nature Publications.)

The relevant studies on RE oxide metallurgy technology have been primarily carried out under laboratory conditions, and the addition amount of RE is more than $150 \mathrm{ppm}$ for the mold casting process used. In the actual process of continuous casting, the contact reactions between $\mathrm{RE}$ and air, steel slag, and refractory may cause problems such as large RE burning loss, low yield, erosion of refractory, SEN clogging, and so on [75]. How to achieve RE oxide metallurgy and stabilization control of RE under the condition of ensuring continuous casting is the key to restricting the industrial application of RE. The addition time, amount and homogenization control of RE, and the high density of RE deoxidation products that are difficult to remove are also problems that need to be addressed at present. Therefore, corresponding studies need to be developed from the 
aspects of purity and addition method of RE alloy, the compositions of refractory, stirring, and flow field distribution of liquid steel.

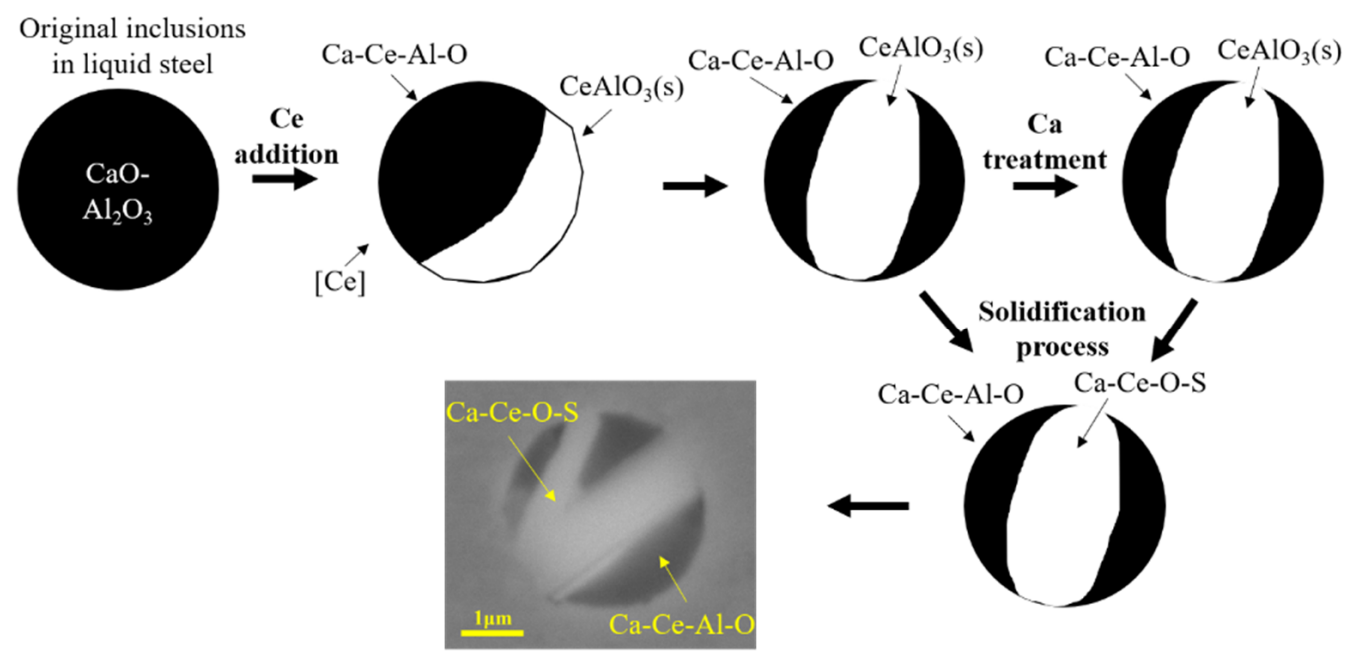

Figure 9. Evolution mechanism of inclusions in refining process. (Reproduced with permission from [74]. Copyright 2021 Iron and Steel Institute of Japan Publications.)

The carbon equivalents of most experimental steel products are less than $0.4 \%$ in previous research. The AF in HAZ is induced through controlling the formation of RE inclusions, and the welding toughness can be improved accordingly. For high strength steel with high carbon equivalent, however, the brittle structures such as upper bainite and granular bainite (consisting of ferrite and M-A structure) are easily formed in HAZ, whereas AF is difficult to form, leading to the traditional idea that oxide metallurgy cannot be applied. Thus, the weldability of high strength steel with high carbon equivalent and the effects of RE on the microstructure and properties of its HAZ must be explored further.

\section{Research on Improving Weldability of High Strength Steel with High Carbon Equivalent}

\subsection{Research Status of Weldability in High Strength Steel with High Carbon Equivalent}

The carbon equivalent of high strength steel with high carbon equivalent is usually more than $0.4 \%$. This is located in Zone II (Figure 2) due to the high carbon content and carbon equivalent. The microstructure of HAZ in this type of steel is different from that of high strength steel with low carbon equivalent (ferrite, pearlite, etc.), so the mechanism of toughness deterioration is also different. Guo et al. [76] studied the microstructure and properties of welded joints in Q690C low carbon bainite steel. The results indicated that large parallel upper bainite lath bundles and M-A structure were formed in the welding fusion zone and coarse grain zone, which caused the hardening of HAZ and affected the impact toughness of welded joints. By adopting the methods of simulated welding, Shi et al. [77] studied the effect of cooling speed on HAZ of $800 \mathrm{MPa}$ high strength steel. It was concluded that the austenite grain size increased with $t_{8 / 5}$ extended; furthermore, the volume fraction of martensite decreased, the quantity of granular bainite increased, and the fracture toughness of HAZ decreased. Wang et al. [78] studied the microstructure changes of HAZ in $\mathrm{Nb}$-Ti-Mo microalloyed steel with hot rolled $8 \mathrm{~mm}$ thick under different welding heat input and found that the austenite grain size increased significantly with the heat input raised. In addition, the fraction of martensite lath decreased and the fraction of granular bainite increased, as shown in Figure 10. The results proved that the coarsening of austenite grain and the formation of upper bainite and M-A structure in HAZ of high strength steel with high carbon equivalent are the important factors affecting weldability. 

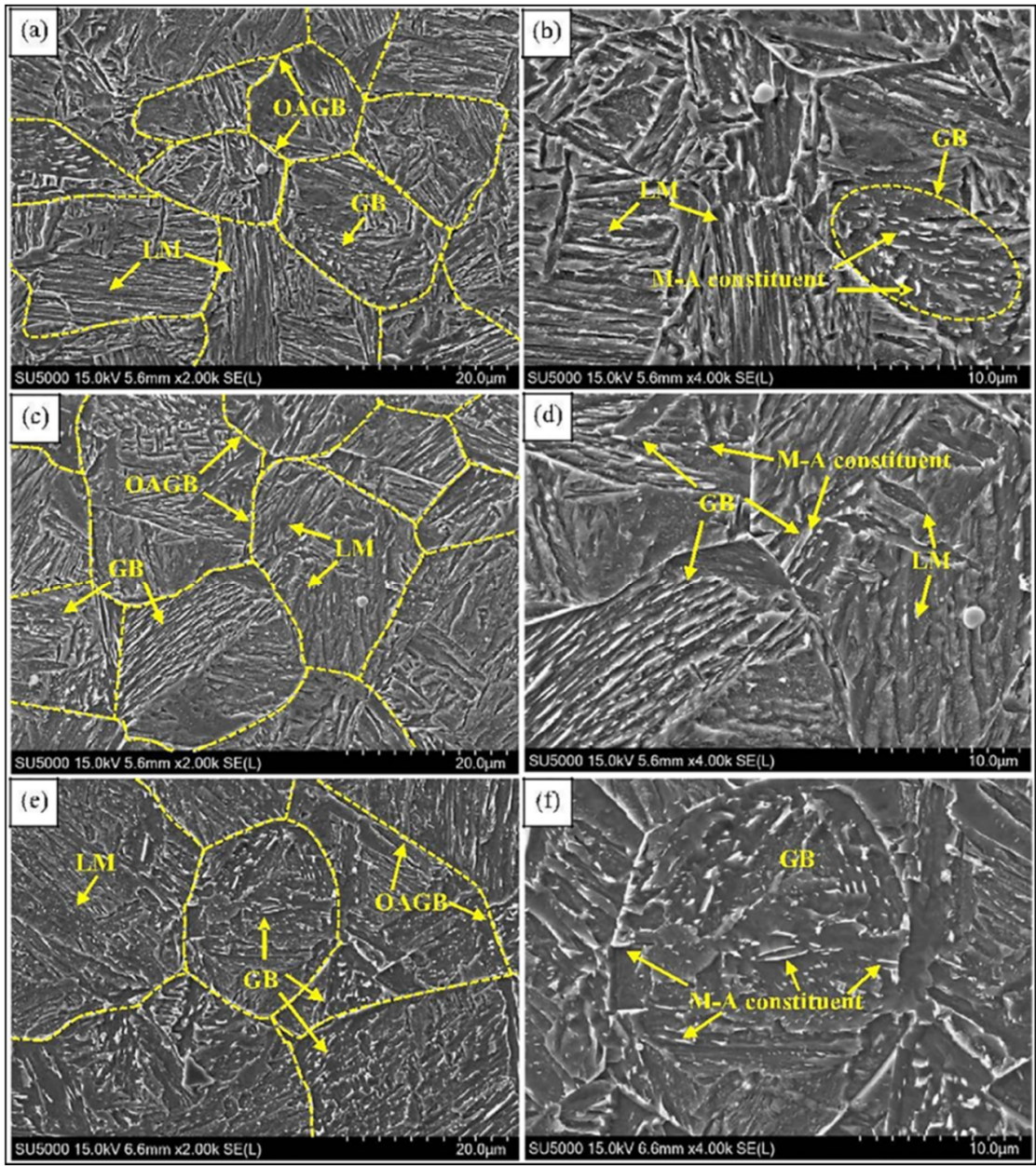

Figure 10. Microstructure of HAZ in high strength steel: (a,b) $3.9 \mathrm{~kJ} / \mathrm{cm} ;(\mathbf{c}, \mathbf{d}) 5.2 \mathrm{~kJ} / \mathrm{cm} ;(\mathbf{e}, \mathbf{f}) 7.75 \mathrm{~kJ} / \mathrm{cm}$. (Reproduced with permission from [78]. Copyright 2017 Elsevier Publications.)

The previous studies on the weldability of this type of high strength steel mostly focus on the welding field, such as welding methods, welding wire composition and properties, preheating and heat treatment after welding, and heat input. The purposes are to obtain the structure with excellent comprehensive performance in the welding cooling. When studying the welding process of $900 \mathrm{MPa}$ high strength steel, Gao et al. [79] adopted the methods of setting the preheating temperature above $125^{\circ} \mathrm{C}$, controlling the heat input with $1.04 \mathrm{~kJ} / \mathrm{cm}$, and adopting the temperature between weld beads to $150^{\circ} \mathrm{C}$ to improve the tensile and impact properties of welded joints and prevent the generation of cold cracks. Xu [80] welded Q890/Q960 shaped steel with three different welding wires; the results indicated that the root crack rates of the welded joint with the three welding wires were less than $20 \%$ with preheating temperature of $100 \sim 150{ }^{\circ} \mathrm{C}$ and the heat input of $12 \sim 20 \mathrm{~kJ} / \mathrm{cm}$. Although the measures noted are beneficial to improving the welding toughness and reducing the cold crack, they will inevitably increase the welding cost and decrease the production efficiency. Therefore, the studies on improving the weldability of the base metal should be continued. By combining the function mechanisms in steel, RE can be fully used to improve the microstructure and welding toughness of HAZ.

\subsection{Effect of RE on Weldability in High Strength Steel with High Carbon Equivalent}

According to microalloying, RE in solid solution affects the microstructure transformation and grain size in steel. Through observing the continuous cooling transformation (CCT) curve and microstructure of RE containing steel, Liu et al. [81] found that RE made the entire CCT curve change downward to the right, the stability of undercooled austenite 
was increased, and the precipitation of proeutectoid ferrite and the transformation of bainite were delayed. The segregation of RE on grain boundaries and dislocation lines not only blocks carbon diffusion and carbide precipitation, affects the distribution of carbide among ferrite lath, and delays the formation of feathery upper bainite [82], but also decreases stacking fault energy of austenite, weakens martensite nucleation, and refines martensite lath [83].

Wang et al. [84] studied the influence of different Ce content on the transformation and morphology of pearlite in heavy rail steel, and it was concluded that RE could significantly inhibit the growth of austenite grain, as shown in Table 2. Relevant studies also indicated that the enrichment of RE at the grain boundary decreased the grain boundary energy and surface tension of austenite, reduced the driving force of grain growth, and promoted grain refinement [85]. Moreover, RE could homogenize the austenite grain size and increase the proportion of large angle grain boundaries, hindering the formation and propagation of cracks and effectively improving the strength and toughness of steel [86].

Table 2. Effect of Ce on austenite grain size. (Reproduced with permission from [84]. Copyright 1994 China Academic Journal Electronic Publications.)

\begin{tabular}{ccccc}
\hline \multirow{2}{*}{ Solid Solubility of Ce/\% } & \multicolumn{4}{c}{ Grain Size at Different Temperatures $(\boldsymbol{\mu m})$} \\
\cline { 2 - 5 } & $\mathbf{1 0 7 3 ~ K}$ & $\mathbf{1 1 2 3} \mathbf{~}$ & $\mathbf{1 1 7 3 ~ K}$ & $\mathbf{1 2 2 3} \mathbf{~ K}$ \\
\hline 0 & 11.1 & 12.7 & 12.9 & 20.3 \\
0.0097 & 8.6 & 9.5 & 10.8 & 12.5 \\
0.0399 & 7.5 & 7.7 & 8.1 & 9.5 \\
0.0977 & 6.2 & 6.4 & 6.5 & 6.7 \\
\hline
\end{tabular}

Previous studies have shown that it is feasible to apply RE and RE inclusions to affect the microstructure and grain of high strength steel with high carbon equivalent, improving the weldability of steel [87,88]. Lu et al. [89] studied the effects of Ce on the microstructure and toughness of $\mathrm{HAZ}$ in $700 \mathrm{MPa}$ high strength steel. The results indicated that Ce delayed the bainite transformation, and the fine RE inclusions pinned the austenite grain boundary and increased the toughness. Similar results were obtained in subsequent research; Lu believed that RE improved the welding toughness of steel [90,91]. Geng et al. [92] analyzed the influence of Ce on the precipitation of inclusions in $700 \mathrm{MPa}$ high strength steel and the properties of HAZ and found that RE and RE inclusions in Ce containing steel could also pin austenite grain boundaries, improve the crack propagation resistance of HAZ, and increase the mechanical properties, as shown in Figure 11. Therefore, the characteristics that RE and RE inclusions affecting the upper bainite transformation, refining the martensite lath and the austenite grain, and pinning the grain boundary can be used to reduce the brittle structure of HAZ.

Furthermore, microalloys such as $\mathrm{Ti}, \mathrm{Nb}, \mathrm{Cr}$, and $\mathrm{V}$ are usually added into high strength steels. Many fine and dispersed Nb, Ti carbonitrides precipitate during hot deformation and heat treatment, which significantly improves the strength and toughness of the base metal due to grain refining and precipitation strengthening. The second phase $(\mathrm{Nb}, \mathrm{Ti}$ carbonitrides) can also improve the welding toughness of the steel by pinning the austenite grain boundary and inhibiting the grain growth. For the evolution behaviors of different second phases, such as Ostwald ripening, dissolution and precipitation in welding thermal cycle greatly affect the microstructure and properties of HAZ in high strength steel. Thus, it is necessary to study the relationship between RE and the temperature, quantity, and size of the second phase precipitation in steel. Lin et al. [93] studied the effect of $\mathrm{RE}$ in $\mathrm{Nb}(\mathrm{Ti}, \mathrm{V})$ microalloyed steel on the precipitation of second phases such as $\mathrm{Nb}(\mathrm{C}, \mathrm{N}),(\mathrm{Nb}, \mathrm{Ti})(\mathrm{C}, \mathrm{N})$, and $\mathrm{V}(\mathrm{C}, \mathrm{N})$. The results indicated that $\mathrm{RE}$ reduced the complete dissolution temperature of the second phase, inhibited its precipitation in the austenite zone, and promoted its precipitation in the ferrite zone through increasing the incubation period and decreasing the precipitation rate. The research results of Zhou et al. [94] also showed that RE could increase the precipitation rate and quantity of $\mathrm{V}(\mathrm{C}, \mathrm{N})$ in the ferrite zone. You et al. [95] 
studied the interaction between La and alloy elements in bcc-Fe from the perspective of the electron layer and believed that the mutual repulsion between $\mathrm{La}$ and $\mathrm{Nb}$ promoted the precipitation of $\mathrm{NbC}$ in the ferrite zone.
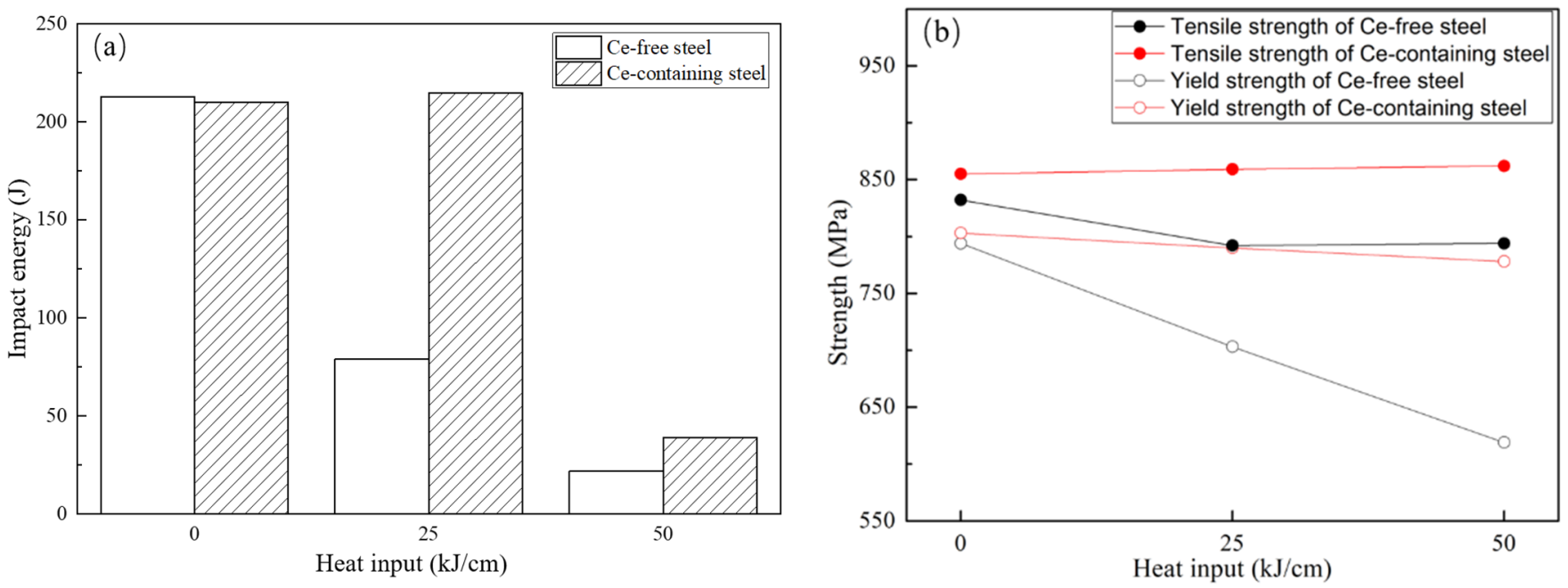

Figure 11. Mechanical properties of HAZ in Ce-free and Ce-containing steel: (a) effect of heat input on impact energy; (b) effect of heat input on strength. (Reproduced with permission from [92]. Copyright 2021 Taylor \& Francis Publications.)

However, there are few reports on the accurate determination of RE in solid solution. The dissolution and precipitation behavior of $\mathrm{Ti}, \mathrm{Nb}$, and $\mathrm{V}$ in austenite and ferrite lack quantitative experimental measurement, and the corresponding thermodynamic and kinetic calculations should be systematically studied. In addition, whether the pinning effect of disperse high melting point RE inclusions on austenite grain boundary is consistent with that of the second phase in the welding process of high strength steel and their contributions need to be explored.

\section{Conclusions}

With the deepening of relevant research, the mechanism of oxide metallurgy technology on the weldability of high strength steel is increasingly clear, but there are still application difficulties and content to be further studied. The following conclusions are drawn by analyzing the application of oxide metallurgy technology and RE:

(1) Optimizing the alloy content in high strength steel and controlling the austenite grain size and cooling speed can help to improve the microstructure and properties of HAZ. Based on the principle of oxide metallurgy technology, the additions of $\mathrm{Ti}, \mathrm{Ca}, \mathrm{Mg}$, and $\mathrm{Zr}$ can form fine and dispersed inclusion particles in steel, which effectively pin austenite grain boundary and induce AF nucleation, leading to enhancing the welding toughness of high strength steel.

(2) Adding an appropriate amount of RE into high strength steel-low carbon equivalent can purify liquid steel and modify inclusions. The disperse high melting point RE inclusions are also able to pin grain boundary and promote the nucleation of $\mathrm{AF}$, and thus can improve the fracture toughness of HAZ. However, it is necessary to further study the effect of key trace elements on RE inclusions, the coordinated control of RE with $\mathrm{O}$ and $\mathrm{S}$, the effective control of RE inclusion size, and the stable control of RE content in steel.

(3) The improvement of weldability of high strength steel with high carbon equivalent is still a technical difficulty in industrial production. To solve the weldability problem, $\mathrm{RE}$ and RE inclusions are able to improve the microstructure and properties of HAZ by acting on microstructure transformation, grain refinement, and pinning grain boundary. The mechanisms of dissolution, precipitation, and pinning grain boundary 
of the second phase, and the pinning mechanism of RE inclusions need to be further analyzed in RE containing steel.

\begin{abstract}
Author Contributions: Conceptualization, W.L., J.Z. and J.L.; methodology, W.L. and R.G.; writingoriginal draft preparation, W.L.; writing-review and editing, W.L., R.G. and F.H.; supervision, J.L.; funding acquisition, J.Z. All authors have read and agreed to the published version of the manuscript.
\end{abstract}

Funding: This research was funded by the Natural Science Foundation of Inner Mongolia Autonomous Region of China, grant number 2020MS0517, the Science and Technology Project of Inner Mongolia Autonomous Region of China, grant number 2020GG0109. And The APC was funded by J.Z.

Institutional Review Board Statement: Not applicable.

Informed Consent Statement: Not applicable.

Data Availability Statement: Not applicable.

Acknowledgments: The authors are grateful for the financial support of the Natural Science Foundation of Inner Mongolia Autonomous Region of China (No. 2020MS0517) and Science and Technology Project of Inner Mongolia Autonomous Region of China (No. 2020GG0109).

Conflicts of Interest: The authors declare no conflict of interest.

\title{
References
}

1. Li, Y.J.; Wang, J.; Liu, P. Welding and Engineering Application of Low Alloy Steel; Chemical Industry Press: Beijing, China, 2003.

2. Xie, Z.J.; Fang, Y.P.; Han, G.; Guo, H.; Misra, R.D.K.; Shang, C.J. Structure-property relationship in a 960 MPa grade ultrahigh strength low carbon niobium-vanadium microalloyed steel: The significance of high frequency induction tempering. Mater. Sci. Eng. A 2014, 618, 112-117. [CrossRef]

3. Li, D.Z.; Suo, Z.G.; Cui, T.X.; Meng, C.F. Research status and progress on production of low carbon alloying and high strength steel with TMCP process. J. Iron Steel Res. 2016, 28, 1-7.

4. Lou, H.N.; Wang, C.; Wang, B.X.; Wang, Z.D.; Misra, R.D.K. Effect of Ti-Mg-Ca treatment on properties of heat-affected zone after high heat input welding. J. Iron Steel Res. Int. 2019, 26, 501-511. [CrossRef]

5. Wan, X.L.; Wu, K.M.; Huang, G.; Wei, R. In situ observations of the formation of fine-grained mixed microstructures of acicular ferrite and bainite in the simulated coarse-grained heated-affected zone. Steel Res. Int. 2014, 85, 243-250. [CrossRef]

6. Takamura, R.; Mizoguchi, Z.S.; Yin, X.D.; Chen, Z.P. Effect of oxides on steel properties. World Iron Steel $2005,5,8-11$.

7. Li, C.L. New progress in application and research of rare earth in steel. Rare Earth 2013, 34, 78-85.

8. Cui, X.K.; Song, B.; Yang, Z.B.; Liu, Z.; Li, L.F.; Wang, L. Effect of Mg on the evolution of inclusions and formation of acicular ferrite in La-Ti-treated steels. Steel Res. Int. 2020, 91, 1900563. [CrossRef]

9. Wang, H.; Bao, Y.P.; Zhi, J.G.; Duan, C.Y.; Wang, M. Effect of rare earth ce on the morphology and distribution of $\mathrm{Al}_{2} \mathrm{O}_{3}$ inclusions in high strength IF steel containing phosphorus during continuous casting and rolling process. ISIJ Int. 2021, 61, 657-666. [CrossRef]

10. Cao, Y.X.; Wan, X.L.; Hou, Y.H.; Niu, C.R.; Liu, Y.; Li, G.Q. In situ observation of grain refinement in the simulated heat-affected zone of Al-Ti-0.05\% Ce-deoxidized steel. Steel Res. Int. 2019, 90, 1900084. [CrossRef]

11. Lee, J.L.; Pan, Y.T. The formation of intragranular acicular ferrite in simulated heat-affected zone. ISIJ Int. 1995, 35, 1027-1033. [CrossRef]

12. Liu, Z.Z.; Kobayashi, Y.; Yin, F.X.; Kuwabara, M.; Nagai, K. Nucleation of acicular ferrite on sulfide inclusion during rapid solidification of low carbon steel. ISIJ Int. 2007, 47, 1781-1788. [CrossRef]

13. Yang, J.; Zhu, K.; Wang, G. Progress in the technological development of oxide metallurgy for manufacturing steel plates with excellent HAZ toughness. Baosteel Tech. Res. 2008, 2, 43-50.

14. Shim, J.H.; Byun, J.S.; Cho, Y.W.; Oh, Y.J.; Dong, N.L. Mn absorption characteristics of $\mathrm{Ti}_{2} \mathrm{O}_{3}$ inclusions in low carbon steels. Scr. Mater. 2001, 44, 49-54. [CrossRef]

15. Manohar, P.A.; Chandra, T. Continuous cooling transformation behaviour of high strength microalloyed steels for linepipe applications. ISIJ Int. 1998, 38, 766-774. [CrossRef]

16. Babu, S.S.; David, S.A. Inclusion formation and microstructure evolution in low alloy steel welds. ISIJ Int. 2002, 42, 1344-1353. [CrossRef]

17. Qi, X.G.; Cheng, M.A.; Chen, J.H.; Shang, X.Q. Microstructure and toughness of welded coarse grain heat affected zone of Ti Nb microalloyed steel. Met. Form. Process 2004, 22, 30-33.

18. Seo, J.S.; Kim, H.J.; Lee, C. Effect of Ti addition on weld microstructure and inclusion characteristics of bainitic GMA welds. ISIJ Int. 2013, 53, 880-886. [CrossRef] 
19. Yin, G.Q.; Yang, C.F.; Wang, S.J. Second phase particles and intragranular ferrite nucleation in microalloyed VN steels. Iron Steel 2005, 40, 315-319.

20. Li, Y.L. Study on Composition Design and Microstructure Control of 700 MPa High Strength Automobile Girder Steel; University of Science and Technology: Beijing, China, 2017.

21. Song, F.M.; Li, Z.G.; Qian, Y.H.; Shen, K. Research progress of structural steel for high line energy welding. Hot Work. Process 2006, 35, 69-73.

22. Yamamoto, K.; Hasegawa, T.; Takamura, J.I. Effect of Boron on Intra-granular Ferrite Formation in Ti-Oxide Bearing Steels ISIJ Int. 1996, 36, 80-86. [CrossRef]

23. Zheng, L. Relationship between carbon content, carbon equivalent and weldability of pipeline steel. Welded Pipe 2004, 27, 72-73.

24. Shome, M. Effect of heat-input on austenite grain size in the heat-affected zone of HSLA-100 steel. Mater. Sci. Eng. A 2007, 445, 454-460. [CrossRef]

25. Gladmin, T.; Pickring, F.B. Grain coarsening of austenite. J. Iron Steel Res. Int. 1967, 205, 653.

26. Madariaga, I.; Gutiérrez, I.; Andrés, G.D.; Capdevila, C. Acicular ferrite formation in a medium carbon steel with a two stage continuous cooling. Scr. Mater. 1999, 41, 229-235. [CrossRef]

27. Zhang, L.; Pittner, A.; Michael, T.; Rhode, M. Effect of cooling rate on microstructure and properties of microalloyed HSLA steel weld metals. Sci. Technol. Weld. Join. 2015, 20,371-377. [CrossRef]

28. Fang, F.; Yong, Q.L.; Yang, C.F.; Hang, S. Microstructure and precipitation behavior in heat affected zone of nitrogen-enhanced microalloyed steel containing V and Ti. J. Iron Steel Res. Int. 2007, 14, 249-253. [CrossRef]

29. Hu, J.; Du, L.X.; Wang, J.J.; Gao, C.R. Effect of welding heat input on microstructures and toughness in simulated CGHAZ of V-N high strength steel. Mater. Sci. Eng. A 2013, 577, 161-168. [CrossRef]

30. Minagawa, M.; Ishida, K.; Funatsu, Y. 390 MPa yield strength steel plate for large heat -input welding for large container ships Nippon. Steel Tech. Rep. 2004, 6, 7-10.

31. Kojima, A.; Kiyose, A.; Uemori, R.; Minagawa, M.; Yasui, H. Super high HAZ toughness technology with fine microstructure imparted by fine particles. Nippon. Steel Tech. Rep. 2004, 6, 2-6.

32. Genichi, S. Progress of high performance steel plates with excellent HAZ toughness. Nippon. Steel Tech. Rep. 2018, 119, $22-25$.

33. Koichi, N.; Kazukuni, H.; Taiki, E. Development of shipbuilding steel plate with superior low temperature toughness for large heat input welding. JFE GIHO 2014, 33, 7-12.

34. Katsuyuki, I.; Takaki, F.; Shinichi, S. Offshore structural steel plates for extreme low temperature service with excellent HAZ toughness. JFE GIHO 2014, 45455, 19-24.

35. Masao, Y.; Masayuki, H.; Shinichi, S. Steel plates with excellent HAZ toughness for offshore structures. JFE Tech. Rep. 2012, 18, 41-47.

36. Hayashi, K.; Araki, K.; Abe, T. High performance for tank and pressure vessel use high strength steel plates with excellent weld-ability and superior toughness for the energy industry. JFE Tech. Rep. 2005, 5, 66-73.

37. Hatano, H.; Nakagawa, T.; Sugino, T.; Hara, N. Effect of Ti and B on microstructure of 780 MPa class high strength steel weld metal. Tetsu-Hagane 2005, 91, 397-402. [CrossRef]

38. Kato, T.; Sato, S.; Ohta, H.; Shiwaku, T. Effects of Ca addition on formation behavior of TiN particles and HAZ toughness in large-heat-input welding. Kobelco Technol. Rev. 2011, 61, 32-35.

39. Liao, W. Core strength and high-function products in the heavy plate field of Kobe Steel Company. Metall. Manag. 2010, 1, 53-57.

40. Ding, Q.F.; Hu, Y.H.; Du, M.; Chen, F.; Liu, W.B.; Wang, X.J. Welding performance analysis of $12 \mathrm{MnNiVR}$ steel plate for large crude oil storage tank. WISCO Technol. 2012, 50, 20-22.

41. Chen, X.; Bu, Y.; Xi, T.H. Research and development progress of WISCO large line input welding series steel. Prog. Mater. China 2011, 30, 34-39.

42. Yang, J.; Zhu, K.; Wang, R.Z.; Wang, G.D.; Shen, J.G. Development of oxide metallurgy process using strong deoxidizer at Baosteel In Proceedings of the 7th China Iron and Steel Annual Conference, Beijing, China, 11 November 2009.

43. Lv, C.F.; Shang, D.L.; Yu, G.W.; Kang, L. Effects of different deoxidation processes on microstructure and mechanical properties of microalloyed steel. Cast. Technol. 2010, 031, 1004-1009.

44. Yang, J.; Xu, L.; Zhu, K.; Wang, R.Z.; Zhou, L.J.; Wang, W.L. Improvement of HAZ Toughness of steel plate for high heat input welding by inclusion control with Mg deoxidation. Steel Res. Int. 2015, 86, 619-625. [CrossRef]

45. Xu, L.; Yang, J. Effects of Mg content on characteristics of nanoscale TiN particles and toughness of heat-affected zones of steel plates after high-heat-input welding. Metall. Mater. Trans. A 2020, 51, 4540-4548. [CrossRef]

46. Xu, L.Y.; Yang, J.; Park, J.; Ono, H. Mechanism of improving heat-affected zone toughness of steel plate with Mg deoxidation after high-heat-input welding. Metals 2020, 10, 162. [CrossRef]

47. Shi, M.H.; Zhang, P.Y.; Liu, J.Y.; Zhu, F.X. Toughness and microstructure analysis of coarse grain heat affected zone of Zr microalloyed steel. Mater. Sci. Technol. 2013, 21,1-5.

48. Shi, Z.R.; Wang, R.Z.; Su, H.; Chai, F.; Wang, Q.F.; Yang, C.F. Effect of nitrogen content on the second phase particles in V-Ti microalloyed shipbuilding steel during weld thermal cycling. Mater. Des. 2016, 96, 241-250. [CrossRef]

49. Deng, X.X.; Wang, X.H.; Jiang, M.; Hu, Z.Y.; Shao, X.J.; Wang, W.J. Effect of inclusions in rare earth treated steel on the for-mation of intragranular acicular ferrite. Chin. J. Eng. 2012, 34, 535-540. 
50. Wan, X.L.; Li, G.Q.; Wu, K.M. Microstructure characteristics and formation mechanism of needle ferrite in low alloy high strength steel. J. Iron Steel Res. 2016, 25, 1-12.

51. Xia, W.Y. Research on Key Metallurgical Technologies of High-Strength Hull Steel Welded with Large Line Energy; General Iron and Steel Research Institute: Beijing, China, 2012.

52. Zhu, L.G.; Sun, L.G. Oxide metallurgy technology and its application and prospect in the development of hull steel. Steelmaking 2017, 33, 1-11.

53. Li, J.; Geng, R.M.; Shi, C.B. A Method of Using Rare Earth to Improve the Toughness of Welding Heat Affected Zone of Low Carbon Equivalent Steel Plate. China Patent 201910245646.9, 25 May 2019.

54. Luo, D.; Xing, G.H.; Zou, H.L.; Yan, S.S.; Yu, Z.Z.; Luo, X.H. Segregation of S and P along grain boundary in high speed steels and cleaning action of RE elements. Acta Met. Sin. 1983, 19, 121-126.

55. Chen, S.B. Development of Thermal Fatigue Test Device and Thermal Fatigue Test of 21-4N Steel; Southeast University: Nanjing, China, 2008.

56. Lu, W.; Liu, H.; Hsu, T.Y.; Xu, Z.Y. Segregation of rare earth during isothermal transformation in low carbon steels. Scr. Metall. Mater. 1993, 29, 273-274. [CrossRef]

57. Yu, S.F.; Deng, Y.; Huang, A.G.; Xu, H.Z. Role of rare earth Ce in weld metal with high heat input. Chin. Sci. Pap. 2012, 7, 612-615.

58. Deng, X.X.; Jiang, M.; Wang, X.H. Mechanisms of inclusion evolution and intra-granular acicular ferrite formation in steels containing rare earth elements. Acta Metall. Sin. 2012, 25, 241-248.

59. Thewlis, G. Effect of cerium sulphide particle dispersions on acicular ferrite microstructure development in steels. Mater. Sci. Technol. 2013, 22, 153-166. [CrossRef]

60. Xue, H.T.; Li, Y.Y.; Cui, C.X.; Wang, B.S. Effect and mechanism of rare earth oxides on microstructure and properties of welds Welding 2007, 06, 31-33+36.

61. Wen, B.; Song, B. In Situ observation of the evolution of intragranular acicular ferrite at Ce-containing inclusions in $16 \mathrm{Mn}$ steel. Steel Res. Int. 2012, 83, 487-495.

62. Nako, H.; Okazaki, Y.; Speer, J.G. Acicular ferrite formation on Ti-rare earth metal-Zr complex oxides. ISIJ Int. 2015, 55, 250-256. [CrossRef]

63. Chu, R.S.; Fan, Y.; Li, Z.J.; Liu, J.G.; Yin, N.; Hao, N. Study on the control of rare earth metals and their behaviors in the industrial practical production of Q420q structural bridge steel plate. Met.-Open Access Metall. J. 2018, 8, 240-250. [CrossRef]

64. Song, M.M.; Xie, Y.M.; Song, B.; Xue, Z.L.; Xu, R.S. The microstructure and property of the heat affected zone in C-Mn steel treated by rare earth. High Temp. Mater. Processes 2019, 38, 362-369. [CrossRef]

65. Xie, Y.M.; Song, M.M.; Wang, F.F.; Xue, Z.L.; Wang, W. Influence of Al deoxidation on the formation of acicular ferrite in steel containing La. High Temp. Mater. Processes 2020, 39, 236-246. [CrossRef]

66. Song, M.M. Effect of Rare Earth on Acicular Ferrite Formation in C-Mn Steel; University of Science and Technology: Beijing, China, 2016.

67. Madariaga, I.; Gutiérrez, I. Role of the particle-matrix interface on the nucleation of acicular ferrite in a medium carbon microalloyed steel. Acta Mater. 1999, 47, 951-956. [CrossRef]

68. Wen, B.; Song, B.; Pan, N.; Yu, Q.Y.; Mao, J.H. Effect of austenitizing temperature on microstructure in $16 \mathrm{Mn}$ steel treated by cerium. Int. J. Miner. Metall. Mater. 2011, 18, 652-658. [CrossRef]

69. Koseki, T. A review on inclusion-assisted microstmcture control in C-Mn and low-alloy steel welds. Weld. World 2005, 49, 22-28. [CrossRef]

70. Deng, X.X.; Wang, X.H.; Jiang, M.; Hu, Z.Y.; Wang, W.J. Effect of inclusions on the formation of intra-granular acicular ferrite in steels containing rare earth elements. J. Univ. Sci. Technol. Beijing 2012, 34, 535-540.

71. Cui, X.; Song, B.; Mao, J. Evolution of inclusions in Mg-RE-Ti treated steels with different Al contents and their influence on acicular ferrite. Metall. Res. Technol. 2021, 118, 208-216. [CrossRef]

72. Wang, L.; Song, B.; Yang, Z.B.; Cui, X.K.; Liu, Z.; Sheng, W.S.; Mao, J.H. Effects of Mg and La on the evolution of inclusions and microstructure in Ca-Ti treated steel. Int. J. Miner. Metall. Mater. 2021, 28, 1940-1948. [CrossRef]

73. Liang, W.; Li, J.; Lu, B.; Zhi, J.G.; Liu, Y. Analysis on clogging of submerged entry nozzle in continuous casting of high strength steel with rare earth. J. Iron Steel Res. Int. 2021, 10, 1-10. [CrossRef]

74. Geng, R.M.; Li, J.; Shi, C.B. Evolution of inclusions with Ce addition and Ca treatment in Al-killed steel during RH refining process. ISIJ Int. 2021, 61, 1506-1513. [CrossRef]

75. Tian, C.; Yu, J.; Jin, E.; Wen, T.; Jia, D.; Liu, Z.; Fu, P.; Yuan, L. Effect of interfacial reaction behaviour on the clogging of SEN in the continuous casting of bearing steel containing rare earth elements. J. Alloy. Compd. 2019, 792, 1-7. [CrossRef]

76. Guo, Y.H.; Zhang, G.F.; Yang, Z.Q.; Huang, C. Microstructure and properties of q690c low carbon granular steel multilayer MAG welded joint. J. Weld. 2015, 36, 96-100.

77. Shi, Y.W.; Han, Z.X. Evaluation of fracture toughness of welding heat affected zone of $800 \mathrm{MPa}$ low alloy high strength steel for construction machinery. Hot Work. Process 2006, 35, 1-5.

78. Wang, X.N.; Zhang, S.H.; Zhou, J.; Zhang, M.; Chen, C.J.; Misra, R.D.K. Effect of heat input on microstructure and properties of hybrid fiber laser-arc weld joints of the 800MPa hot-rolled Nb-Ti-Mo microalloyed steels. Opt. Lasers Eng. 2017, 91, 86-96. [CrossRef]

79. Gao, Y.J.; Wang, C.; Xu, Z.L. Welding process of high strength steel with yield strength of 900MPa. J. Weld. 2007, 028, 103-107. 
80. Xu, H. Study on Crack and Heat Affected Zone Structure of GMAW Joint of q890/q960 High Strength Steel; Shandong University: Jinan, China, 2015.

81. Liu, Z.C.; Li, C.J. Effect of rare earth on microstructure transformation of low carbon silicon manganese steel. Weapon Mater. Sci. Eng. 1990, 4, 23-28.

82. Hou, Y.C.; Wang, Y.; Pan, Z.Y.; Yu, L.L. Influence of rare earth nanoparticles and inoculants on performance and microstructure of high chromium cast iron. J. Rare Earths 2012, 30, 283-288. [CrossRef]

83. Li, W.X.; Liu, Z.C.; Li, C.J. Effect of Cerium on continuous cooling transformation of undercooled austenite in $60 \mathrm{mn}^{2}$ steel. J. Baotou Iron Steel Inst. 1990, 2, 44-49.

84. Wang, F.M.; Huang, Z.K.; Guo, X.A.; Wang, L.; Zhang, G.Z.; Han, Q.Y. Effect of Cerium on pearlite transformation and microstructure in heavy rail steel. Chin. J. Rare Earth 1994, 12, 239-242.

85. Zhao, W.X.; Yuan, W.; Jiang, S.H.; Wang, H.; Liu, X.J.; Ping, L.Z. Micro-alloying effects of yttrium on recrystallization behavior of an alumina-forming austenitic stainless steel. J. Iron Steel Res. Int. 2016, 23, 553-558. [CrossRef]

86. Zhao, Y.Y.; Wang, J.F.; Zhou, S.; Wang, X.D. Effects of rare earth addition on microstructure and mechanical properties of a Fe-15Mn-1.5 Al-0.6 C TWIP steel. Mater. Sci. Eng. A 2014, 608, 106-113. [CrossRef]

87. Geng, R.M.; Li, J.; Shi, C.B.; Zhi, J.G.; Lu, B. Effect of Rare Earth on Microstructure and Properties of Welding Heat Affected Zone of 700MPa High Strength Steel. In Proceedings of the 9th International Conference on Effect of Rare Earth on Microstructure and Properties of Welding Heat Affected Zone of 700MPa High Strength Steel. International Symposium on rare earth development and application and annual academic meeting of China Rare Earth Society, Beijing, China, 15-18 May 2019.

88. Shi, C.B.; Li, J.; Lu, B.; Zhi, J.G.; Geng, R.M. A Method of Using Rare Earth to Improve the Toughness of Welding Heat Affected Zone of High Carbon Equivalent Steel Plate. China Patent 201910245642.0, 7 February 2020.

89. Lu, B.; Chen, F.R.; Zhi, J.G.; Geng, R.M. Application of rare earth oxide metallurgy technology to improve the weldability of high strength steel. J. Met. 2020, 56, 1206-1216.

90. Lu, B.; Chen, F.R.; Liu, W.J.; Zhi, J.G. Effect of Cerium on weldability of 700 MPa High Strength Steel for construction machinery. J. Eng. Sci. 2020, 42, 95-101.

91. Lu, B.; Chen, F.R.; Fu, X.Y. Microstructure and properties of welding heat affected zone of a rare earth high strength steel. J. Weld. 2020, 41, 85-89.

92. Geng, R.M.; Li, J.; Shi, C.B. Effect of Ce on inclusion evolution and HAZ mechanical properties of Al-killed high-strength steel. Ironmak. Steelmak. 2021, 48, 796-802. [CrossRef]

93. Lin, Q.; Chen, B.W.; Tang, L.; Song, B.; Zhu, X.Y.; Wang, H.B. Effect of rare earth in microalloyed steel on precipitated phase and properties. Chin. J. Rare Earth 2002, 20, 256-260.

94. Zhou, L.J.; Tang, L.D.; Miao, Z.; Sun, W.H.; Huang, H.Q. Rare earth microalloying and its effect on the Precipitation Law of Vanadium niobium precipitate. Iron Steel Res. 2001, 4, 1-4.

95. You, Y.; Yan, M.F. Behaviors and interactions of La atom with other foreign substitutional atoms (Al, Si, Ti, V, Cr, Mn, Co, Ni, Cu, $\mathrm{Nb}, \mathrm{Mn}$ ) in iron based solid solusion from first principles. Comput. Mater. Sci. 2013, 73, 120-127. [CrossRef] 